\title{
GAMBARAN HISTOPATOLOGI PLASENTA PADA KEHAMILAN DENGAN PREEKLAMPSIA
}

\author{
${ }^{1}$ Samuel Evanov Basana Simbolon \\ ${ }^{2}$ Meilany Durry \\ ${ }^{2}$ Poppy Lintong
}

\author{
${ }^{1}$ Kandidat Skripsi Fakultas Kedokteran Universitas Sam Ratulangi Manado \\ ${ }^{2}$ Bagian Patologi Anatomi Fakultas Kedokteran Universitas Sam Ratulangi Manado \\ Email: ebasana@yahoo.com
}

\begin{abstract}
Pre-eclampsia (PE) is one of the complications of pregnancy (gestation age of more than 20 weeks), characterized by hypertension and edema or proteinuria or both, meanwhile eclampsia is associated with convulsion is called eclampsia. Endothelial dysfunction resulting in a decrease of placental blood perfusion plays an important role in the pathogenesis of PE. Histopathologically, this decrease of perfusion is marked by atherosis, infarct, dan thrombosis in the placenta. This study aimed to obtain the placental histopathological patterns of $\mathrm{PE}$ pregnancies.This was an observational analytical study with a cross sectional design. Twenty placental samples were obtained from mothers with PE. The results showed syncitial knots in all samples $(100 \%)$, increase of cytotrophoblast cells $(100 \%)$, vasodilatation of villi vessels $(100 \%)$, calcification (100\%), obliterative endarteritis (90\%), atherosis and infarction (90\%), thrombosis (75\%), without any villi edema (0\%). Conclusion: Most of placental samples of PE pregnancy showed syncitial knots, increases of cytotrophoblasts, vasodilatation of villi vessels, calcification, obliterative endarteritis, atherosis and infarction, as well as thrombosis.
\end{abstract}

Keywords: pre-eclampsia, placenta, histopathological patterns

Abstrak: Preeklampsi (PE) merupakan salah satu komplikasi kehamilan pada usia kehamilan lebih dari 20 minggu, yang ditandai hipertensi dan salah satu dari tanda-tanda edema, proteinuria atau kedua-duanya, dan jika disertai kejang disebut eklampsi. Disfungsi endotel berperan penting dalam patogenesis PE. Akibat disfungsi endotel terjadi penurunan perfusi darah plasenta. Penurunan perfusi darah plasenta secara histopatologi ditandai oleh atherosis, infark, dan trombosis pada plasenta. Penelitian ini bertujuan untuk mengetahui gambaran histopatologik plasenta pada PE. Penelitian bersifat observasional analitik dengan cross sectional design. Sampel diambil dari plasenta ibu yang melahirkan dengan gejala PE. Hasil penelitian memperlihatkan bahwa pada 20 sampel plasenta wanita hamil dengan PE didapatkan simpul sinsitial pada seluruh pasien (100\%), peningkatan sitotrofoblas pada seluruh pasien(100\%), perubahan vaskularisasi pada vili pada seluruh pasien (100\%), kalsifikasi pada seluruh pasien (100\%), endateritis obliteratif (90\%), atherosis dan infark (90\%), trombosis (75\%), dan tidak ditemukannya edema vili pada keseluruhan sampel pasien (0\%). Simpulan: Gambaran histopatologi plasenta pada PE ialah simpul sinsitial, peningkatan sitotrofoblas, perubahan vaskularisasi vili, kalsifikasi, infark, atherosis, dan trombosis.

Kata Kunci: preeklampsi, plasenta, gambaran histopatologi. 
Preeklampsi (PE) merupakan salah satu komplikasi kehamilan setelah usia kehamilan 20 minggu, yang ditandai hipertensi dan salah satu dari tanda-tanda edema, proteinuria atau kedua-duanya, dan jika disertai kejang disebut eklampsi. ${ }^{1}$ Menurut World Health Organization (WHO), di negara berkembang, kematian maternal berkisar antara 750-1.000 per 100.000 kelahiran hidup. Sedangkan di negara maju kematian maternal berkisar antara 5-10 per 100.000 kelahiran hidup.Berdasarkan Survei Demografi dan Kesehatan Indonesia (SDKI) 2002/2003, Angka Kematian Ibu (AKI) di Indonesia masih berada pada 307 per 100.000 kelahiran hidup atau setiap jam terdapat 2 orang ibu bersalin yang meninggal dunia karena berbagai sebab. Survei terakhir SDKI tahun 2007 AKI Indonesia sebesar 228 per 100.000 kelahiran hidup, meskipun demikian angka tersebut masih tertinggi di Asia. ${ }^{2}$

Beberapa faktor predisposisi yang mempengaruhi terjadinya PE antara lain umur, paritas, keturunan, faktor genetik, diet, lingkungan, sosio-ekonomi, penyakit hipertensi kronis, dan hiperplasentosis. ${ }^{3}$ Penyebab pasti dan patogenesis $\mathrm{PE}$ sampai saat ini masih kontroversi. Patogenesis PE dihubungkan dengan disfungsi sel endotel. Banyak peneliti berpendapat bahwa disfungsi endotel memainkan peranan penting dalam patogenesis PE. Penyebab dari disfungsi endotel adalah multifaktorial. Stress oksidatif, paparan sitokin inflamasi, dan hiperkolestrolemia merupakan beberapa penyebab disfungsi endotel. ${ }^{4}$ Akibat dari disfungsi endotel terjadi penurunan perfusi darah plasenta. Penurunan perfusi plasenta dapat dilihat dari adanya gambaran histopatologi berupa atherosis, infark, dan trombosis pada plasenta. Bayi yang lahir dari ibu PE dapat mengalami asfiksia neonatorum. Hal ini disebabkan karena pada PE terjadi penurunan suplai darah plasenta dan mengakibatkan bayi mengalami hipoksia. ${ }^{5}$
Dalam tulisan ini peneliti ingin meneliti perubahan gambaran histopatologi plasenta pada kehamilan dengan $\mathrm{PE}$

\section{METODE PENELITIAN}

Penelitian ini merupakan observasional analitik dengan rancangan penelitian yang digunakan adalah penelitian potong silang (cross sectional study). Lokasi Bagian Patologi Anatomi FK UNSRAT dan Bagian Obstetri Ginekologi BLU RSUP Prof. dr. R. D. Kandou dengan waktu Oktober-Desember 2012. Sampel diambil dari plasenta ibu yang melahirkan dengan gejala PE di BLU RSUP Prof. dr. R. D. Kandou. Teknik pengambilan sampel yang dilakukan yaitu plasenta dibersihkan dari darah dan bekuan darah, kemudian plasenta ditimbang beratnya. Plasenta dipotong pada 2 tempat ukuran sebesar 2 × 2 $\mathrm{cm}$ di tengah dan di bagian pinggir plasenta difiksasi dalam cairan formalin $10 \%$ untuk pemeriksaan histologi.

\section{HASIL PENELITIAN}

\section{Karekteristik subjek penelitian}

Pada penelitian ini usia pada subyek penelitian berada pada rentang umur 15-39 tahun dimana rentang umur dengan subyek terbanyak adalah 20-24 tahun jumlah 13 orang. Usia kehamilan yang didapatkan untuk keseluruhan masuk pada kriteria aterm 38-39 minggu, dengan tekanan darah lebih sama dengan 120/80 mmHg dan kadar proteinuria positif satu sampai empat.

Pada keseluruhan sampel yang diambil didapatkan hasil yang dimasukkan kedalam tabel indikator pengukuran (Tabel 1).

Gambaran histopatologi seperti simpul sinsitial, peningkatan sito-trofoblas, perubahan vaskularisasi, fibrosis stroma, endateritis obliteratif, atherosis, infark, trombosis, kalsifikasi terlihat pada Gambar 1, 2, 3 dan 4. 
Tabel 1. Indikator penilaian sampel

\begin{tabular}{lcc}
\hline & Jumlah & Persentase \\
\hline Simpul sinsitial & 20 & $100 \%$ \\
Peningkatan sitotrofoblas & 20 & $100 \%$ \\
Edema vili & 0 & $0 \%$ \\
Perubahan vaskularisasi & 20 & $100 \%$ \\
Fibrosis Stroma & 15 & $75 \%$ \\
Endarteritis obliteratif & 18 & $90 \%$ \\
Atherosis & 18 & $90 \%$ \\
Infark & 18 & $90 \%$ \\
Trombosis & 15 & $75 \%$ \\
Kalsifikasi & 20 & $100 \%$ \\
\hline
\end{tabular}

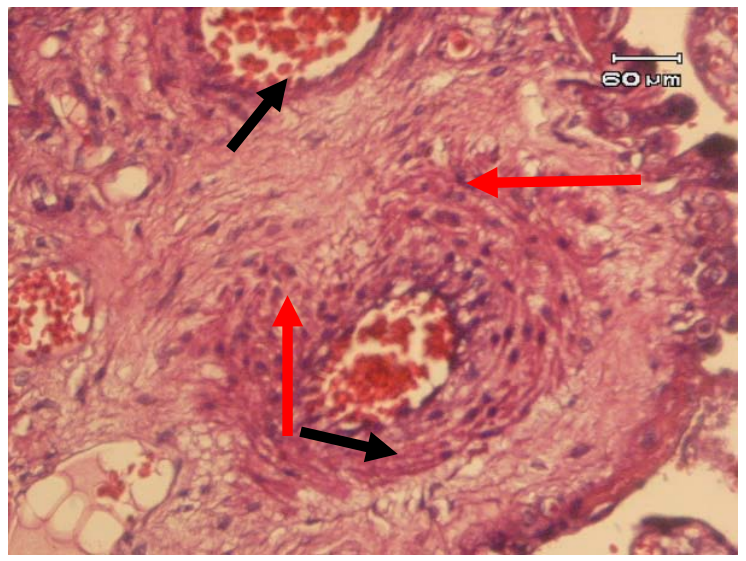

Gambar 1. Gambaran histologi plasenta pada pasien PE yang di potong pada bagian perifer. Terdapat endarteritis obliteratif (panah hitam) dan fibrosis stroma (panah merah).

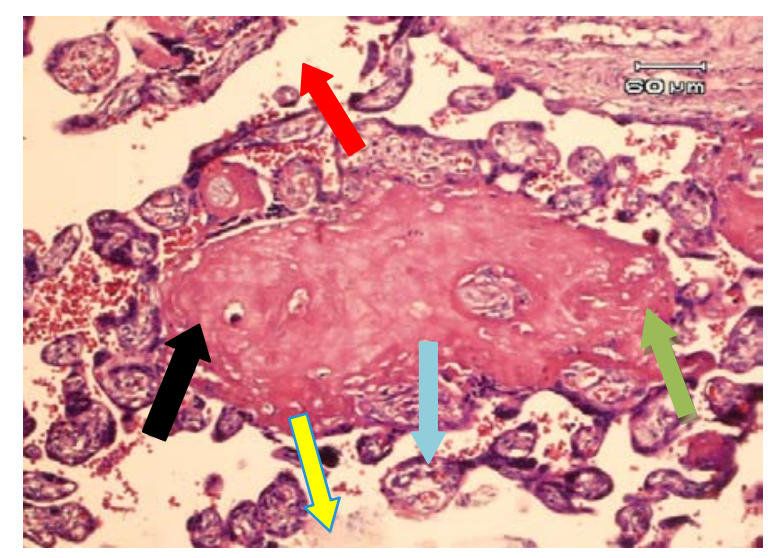

Gambar 2. Gambaran histologi plasenta pada pasien PE yang di potong pada bagian dekat tali pusat. Kalsifikasi (panah merah), simpul sinsitial (panah biru), peningkatan sitotrofoblas (panah kuning), nekrosis (panah hijau), dan trombosis (panah hitam).

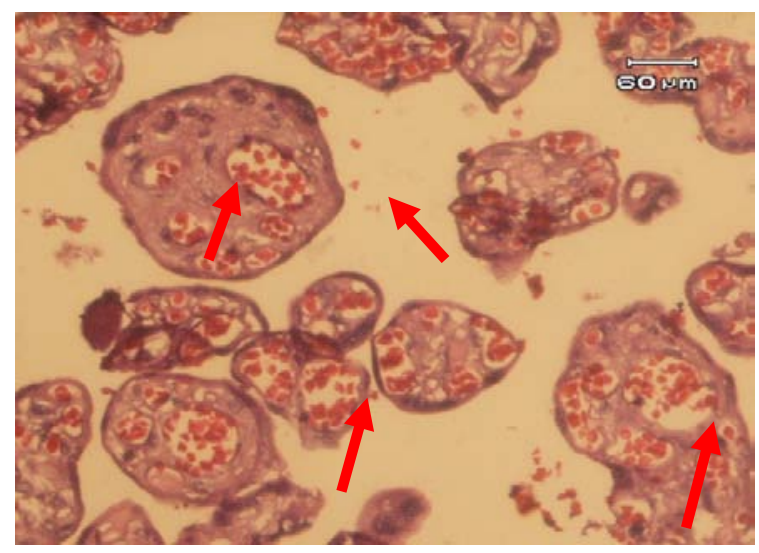

Gambar 3. Gambaran histologi plasenta pada pasien PE yang di potong pada bagian dekat tali pusat. Terdapat perubahan vaskularisasi vili (panah merah).

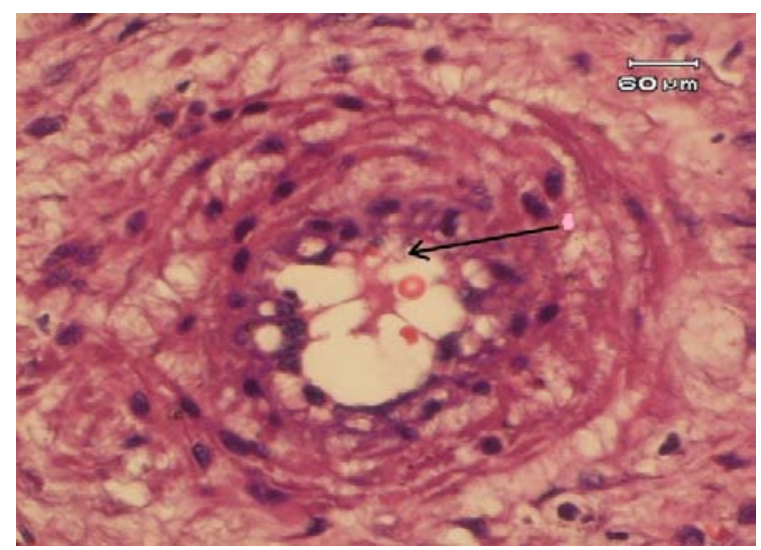

Gambar 4. Gambaran histologi plasenta pada pasien PE yang di potong pada bagian perifer. Terdapat atherosis (panah hitam).

\section{BAHASAN}

Preeklampsi merupakan penyulit pada masa kehamilan dan saat melahirkan, PE juga mempengaruhi berat plasenta yang lahir. Berat plasenta normal yang didapat dalam penelitian ini rata-rata adalah 532 gram. Pada penelitian didapatkan juga dua sampel dengan tingkat proteinuria berat (positif 4) menyebabkan turunnya berat plasenta. Hal ini dapat terjadi karena berkurangnya perfusi oksigen, sehingga jaringan dan pembuluh darah menjadi iskemik dan mengalami nekrosis. Banyaknya jaringan yang mengalami nekrosis akan membuat plasenta menjadi lebih ringan dan terlihat lebih kecil 
dari plasenta normal. ${ }^{10}$

Berdasarkan hasil pemeriksaan histopatologi ditemukanpeningkatan jumlah simpul sinsitial dan pada seluruh sediaan jaringan plasenta (100\%) seperti dalam gambar (Gambar 2). Gambaran ini disebabkan simpul sinsitial memang ada pada plasenta mature, tetapi pada plasenta PE simpul sinsitial ada karena situasi hipoksia yang dialami oleh plasenta. Hipoksia menyebabkan bentuk bagian ujung atau terminal vili menjadi tidak beraturan dan memperbesar kemungkinan penumpukan trofoblas yang menyebabkan terbentuknya simpul sinsitial. ${ }^{6}$

Pada seluruh jaringan plasenta yang diteliti, baik bagian perifer atau dekat dengan tali pusat, terdapat peningkatan jumlah sitotrofoblas. Peningkatan sitotrofoblas merupakan akibat dari kurangnya perfusi oksigen. Pada plasenta matur sel sitotrofoblas akan berkurang, tetapi pada PE banyak vili baru yang terbentuk untuk menunjang kekurangan perfusi plasenta, maka semakin banyak pula sel trofoblas dan vili-vili baru yang terbentuk. Infasi trofoblas yang akan menjadi sitotrofoblas ini terjadi karena perfusi oksigen yang inadekuat. Fungsi sitotrofoblas sendiri adalah tempat terjadinya pertukaran gas dimana sitotrofoblas akan menggantikan fungsi endotel arteriol.

Selain merupakan kompensasi terhadap kebutuhan perfusi yang inadekuat, peningkatan sitotrofoblas juga dipengaruhi oleh Aktivin A. Aktivin A merupakan glikoprotein yang termasuk dalam keluarga Transforming Growth Factor- $\beta$ superfamily, sebuah group protein yang mengontrol proliferasi dan diferensiasi sel dari banyak sistem tubuh. Keadaan hipoksia pada plasenta memicu pengeluaran TNF- $\alpha$ (Tumor Necrosis Factor-alpha) dan IL1 $\beta$ (Interleukin-1Beta) dari plasenta serta suatu faktor yang disebut hipoxia-inducible transcription factor yang akan memacu trofoblas untuk menghasilkan Aktivin A lebih banyak. Hal ini di perlukan untuk memacu sitotrofoblas vilus bermigrasi lebih banyak untuk menjamin suplai oksigen yang adekuat untuk perkembangan janin selama kehamilan. Plasenta normal matur pada tiap vili hanya memiliki 20\% sitotrofoblas, tetapi pada PE keadaan ini meningkat karena fungsi sitotofoblas sendiri yang merupakan pertukaran gas akan meningkat sebagai kompensasi keadaan hipoksia. Pada penelitian ini kita dapat menemukan lebih dari 20\% sitotrofoblas tiap vili. ${ }^{4,9,10}$

Pada sampel jaringan plasenta PE yang diteliti juga di temukan endateritis obliteratif (Gambar 1). Endateritis obliteratif disebabkan karena kurangnya pasokan oksigen kepada pembuluh darah terutama arteriol. Sediaan plasenta yang diteliti, 80\% mengalami endateritis obliteratif dan $20 \%$ tidak terdapat endateritis obliteratif, hal ini diduga karena pasokan oksigen masih dapat menopang kebutuhan oksigen jaringan. Pada saat kurangnya pasokan oksigen ke arteriol maka sel-sel otot polos tunika media akan bermigrasi ke tunika intima dan mengalami proliferasi. Proses iskemik merupakan pemicu proses inflamasi pada dinding endotel. Proliferasi ini ditandai dengan penebalan tunika intima yang mengakibatkan penyempitan pada pembuluh darah.,

Fibrosis stroma juga di temukan dalam sampel jaringan yang diteliti, pada bagian perifer maupun dekat dengan tali pusat (Gambar 1). Pada 75\% dari keseluruhan sampel didapatkan adanya fibrosis stroma, hal ini disebabkan adanya jaringan yang belum mengalami keadaan kekurangan

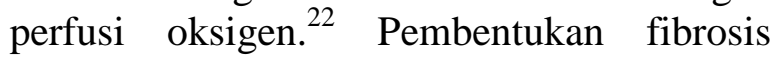
stroma mempunyai kaitan erat dengan gangguan vaskularisasi. Fibrosis juga dapat disebut sebagai proses perbaikan pada jaringan yang rusak dengan adanya proliferasi fibroblastik akibat radang kronis karena hipoksia dan banyak jaringan nekrosis pada pembuluh darah dalam jangka waktu lama. Selain akibat dari proses radang, obstruksi vili akibat adanya penebalan endotel memicu terjadinya fibrosis pada 
stroma pembuluh darah., ${ }^{6,7}$

Perubahan vaskularisasi pada PE juga ditemukan pada setiap sampel plasenta. Pada plasenta PE terjadi perubahan vaskularisasi berupa hipervaskularisasi (Gambar 3), sedangkan pada satu sampel menjadi hipovaskularisasi. Perubahan menjadi hipervaskularisasi disebabkan adanya proses angiogenesis atau pembentukan pembuluh baru.Angiogenesis terjadi karena perfusi oksigen yang berkurang dan merupakan respon normal dari jaringan yang kekurangan oksigen. VEGF (vascular endotelial growth factor) memegang peranan sangat penting dalam pembentukan pembuluh darah baru. Keadaan hipovaskularisasiterdapat pada satu sampel jaringan yang diambil dekat dengan tali pusat. Hal ini kemungkinan terjadi karena beberapa faktor yaitu usia, umur kehamilan, berat plasenta dan tekanan darah. ${ }^{7,8}$

Dasar yang menguatkan adanya atherosis, infark dan trombosis adalah abnormalitas pembuluh darah, aliran darah dan komposisi dari darah (Gambar 2, 4). Pada PE plasenta mengalami keadaan perfusi yang inadekuat sampai perubahan dari arteri spiralis. Plasenta dalam keadaan tersebut mengalami hipoksia, stres oksidatif dan iskemia sehingga mengalami nekrosis dan infark. Pada pemeriksaan jaringan didapatkan 90\% sampel mengalami atherosis dan infark, kesamaan ini didapat karena proses perjalanan yang berkesinambungan di mulai dengan atherosis kemudian diikuti infark. Abnormalitas aliran darah pada PE, mempengaruhi arteri spiral dimana arteri spiral merupakan arteri yang mensuplai vili. Suplai oksigen vili yang berkurang mengakibatkan sel-sel otot polos menuju tunika intima. Proliferasi dari sel-sel otot polos dan pengendapan matriks ekstra selular oleh otot polos di intima merubah bercak perlemakan menjadi atheroma fibrofatty matang dan berperan dalam pertumbuhan progresif lesi aterosklerotik. ${ }^{7}$ Kelainan endotel yang terjadi dapat dilihat adanya selsel busa (Gambar 4).
Kelainan pembuluh darah pada plasenta PE disebabkan karena tidak terjadinya ataupun hanya sebagian dari arteri spiralis yang diinvasi oleh sel-sel trofoblas. Invasi yang terjadi adalah untuk menggantikan dinding dari arteri spiralis yaitu muskuloelastik menjadi dinding yang diisi oleh material-material fibrinoid. Material fibrinoid pada dinding arteri spralis memungkinkan arteri spiralis menyerupai kantong dan mempunyai dinding yang tipis sehingga dapat menyesuaikan dengan aliran darah yang dibutuhkan. Nekrosis yang terjadi karena kurangnya oksigen akibat rusaknya arteri spiralis dan trofoblas yang mengalami hipoksia mengeluarkan tromboksan sebagai faktor vasoaktif yang mengakibatkan terjadi trombosis. Tromboksan sebagai vasoaktif diproduksi sebagai kompensasi adanya kerusakan endotel. Kerusakan endotel juga memicu penurunan dari protasiklin yang dibentuk di endotel. ${ }^{7}$

\section{SIMPULAN DAN SARAN}

Gambaran histologi plasenta wanita hamil dengan PE yang diteliti pada 20 sampel didapatkan simpul sinsitial pada seluruh pasien (100\%), peningkatan sitotrofoblas pada seluruh pasien(100\%), perubahan vaskularisasi pada vili pada seluruh pasien (100\%), kalsifikasi pada seluruh pasien (100\%), endateritis obliteratif pada 18 pasien (90\%), atherosis dan infark pada 18 pasien (90\%), trombosis pada 15 pasien (75\%), trombosis pada 15 pasien (75\%) dan tidak ditemukannya edema vili pada keseluruhan sampel pasien (0\%). Adapun saran dalampenelitisniniyaitu perlu dilakukan penelitian dengan jumlah sampel ditambah serta penelitian yang menilai indikator histopatologi plasenta PE secara kuantitatif. Pada penelitian berikutnya juga bisa dilakukan pemeriksaan molekuler atau imunohistokimia untuk melihat perubahan pada tingkat molekuler plasenta PE. 


\section{UCAPAN TERIMA KASIH}

Ditujukan kepada dr. Meilany Durry selaku Dosen Pembimbing dan Penguji I, dr. Poppy Lintong selaku Dosen Pembimbing dan Penguji II, dan dr. selaku Penguji III serta kepada semua pihak yang baik secara langsung dan tidak langsung telah menumbuhkan ide atau gagasan pada penulis sehingga penulis dapat menyelesaikan artikel ini.

\section{DAFTAR PUSTAKA}

1. Wibowo B, Rachimhadi T. Preeklampsia dan eklampsia, Dalam Ilmu Kebidanan (Edisi Ketiga). Jakarta: Yayasan Bina Pustaka Sarwono Prawirohardjo; 2007.

2. Menegpp. Angka Kematian Ibu Melahirkan. 2008.

3. Taylor CR, Chandrasoma P. Disease of pregnancy trophoblastic neoplasma in concise pathology (Third Edition). USA: Appleton \& Lange, 1998; p.811.

4. Gani S, Tambunan, Wibisono AH, Sufida. Gambaran histopatologi plasenta pada kehamilan normotensif dan kehamilan dengan klinis preeklampsia. Departemen Patologi Anatomi Fakultas Kedokteran
Universitas Sumatera Utara. Majalah Kedokteran Nusantara. 2006;39(1).

5. Sunarto, Suparji, Ayu AK. Hubungan antara hipertensi, proteinuria ibu preeklampsi dengan kejadian asfiksia neonatorum di RSU dr. Harjono S. Ponorogo; 2010

6. Benirschke K, Kaufmann P, Baergen RN. manual of benirschke and kaufmann's pathology of the human placenta. 2005. chapter 5, New York: Springer Science; 2005

7. Kumar, Kotran, Robbins. Pembuluh darah. In: Robbins, editor. Buku ajar Patologi (Edisi Ketujuh). Jakarta: EGC, 2007; p.369-70.

8. Setiabudy RD. Patofisiologi trombosis dalam hemostasis dan trombosis (Edisi Keempat). Jakarta: Fakultas Kedokteran Universitas Indonesia, 2009; p.34

9. Caniggia I, Lye S, Cross J. Activin is a local regulator of human cytotrophoblast cell differentiation. J Endocrinol. 1977;138:3976-86.

10. Benirschke K, Kaufmann P, Baergen RN. Manual of benirschke and kaufmann's pathology of the human placenta. New York: Springer Science, 2005; p.157-9. 